\title{
Degradasi Plastik oleh Bacillus PL01 pada Medium Air Kolam dengan Penambahan Monosodium Glutamat
}

\author{
Auliya Triasita Rizqy dan Maya Shovitri \\ Departemen Biologi, Fakultas Ilmu Alam, Institut Teknologi Sepuluh Nopember (ITS) \\ e-mail: maya@bio.its.ac.id
}

\begin{abstract}
Abstrak-Plastik merupakan suatu komoditi yang sering digunakan dalam kehidupan sehari-hari sehingga tiap tahunnya limbah yang dihasilkan juga semakin meningkat dan menyebabkan permasalahan lingkungan. Tujuan dalam penelitian ini adalah mengetahui pertumbuhan dan degradasi plastik kresek oleh isolat bakteri Bacillus PL01 dan Pseudomonas PL01 pada medium air kolam steril dengan penambahan $1 \mathrm{~g} / \mathrm{L}$ MSG. Bakteri Bacillus PL01 dan Pseudomonas PL01 yang telah terbukti mampu melakukan degradasi plastik. Bacillus sp. dan Pseudomonas sp. merupakan bakteri yang dapat ditemukan pada sedimen perairan yang memanfaatkan nutrisi dalam sedimen dan perairan baik berupa organik maupun anorganik untuk pertumbuhan selnya. Monosodium glutamat (MSG) juga terbukti dapat meningkatkan pertumbuhan bakteri dan membantu dalam proses metabolisme sel. Hasil Penelitian ini adalah setelah minggu ke-12 masa inkubasi pertumbuhan biofilm Bacillus PL01 dengan 1 g/L MSG pada plastik, putih, dan transparan menurun menjadii 0,108; 0,093; 0,107 AU. Sedangkan Pseudomonas PL01 meningkat menjadi 0,187; 0,163; 0,163 AU pada minggu ke-12 masa inkubasi. Velositas pada plastik hitam, putih dan transparan yang telah didegradasi oleh Bacillus PL01 dan Pseudomonas PL01 dengan/tanpa 1 g/L MSG membutuhkan waktu apung lebih lama dibandingkan kontrol tanpa perlakuan.
\end{abstract}

Kata Kunci-Air kolam, Bacillus PL01, Biodegradasi Plastik, MSG, Pseudomonas PL01.

\section{PENDAHULUAN}

$\mathrm{P}$ LASTIK adalah senyawa polimer dengan struktur kaku yang terbentuk dari polimerisasi monomer hidrokarbon yang membentuk rantai panjang [1]. Kantung plastik kresek merupakan plastik yang sering digunakan karena harganya yang murah, praktis, dan mudah didapat. Menurut Inaplast (Asosiasi Industri Aromatik Olefin dan Plastik) memperkirakan bahwa pada tahun 2016 permintaan plastik di Indonesia mencapai 4,65 juta ton [2]. Peningkatan penggunaan plastik yang terjadi tiap tahunnya mengakibatkan limbah yang dihasilkan juga semakin meningkat, sehingga menyebabkan permasalahan lingkungan. Usaha untuk mengurangi limbah plastik dengan daur ulang masih belum optimal, sehingga dibutuhkan alternatif lain untuk mengurangi limbah adalah dengan biodegradasi yang menggunakan mikroorganisme seperti bakteri [3][4], dan [5].

Isolat bakteri Bacillus sp. koleksi Laboratorium Mikrobiologi ITS telah teruji memiliki kemampuan biodegradasi. Monosodium glutamat (MSG) komersial berpengaruh terhadap pertumbuhan isolat Bacillus PL01. MSG adalah garam natrium yang berikatan dengan asam amino berupa asam glutamat [6]. Asam glutamat dan asam amino dapat meningkatkan pertumbuhan sel bakteri [7]. Penelitian sebelumnya melaporkan degradasi plastik kresek dengan Bacillus PL01 dan bakteri indigenous dengan $1 \mathrm{~g} / \mathrm{L}$ MSG pasir dapat mendegradasi plastik kresek transparan, putih, dan hitam mencapai 5\%,4\%, dan 2\% setelah 16 minggu masa inkubasi [8].

Dalam penelitian sebelumnya, biodegradasi plastik dengan isolat bakteri menggunakan mineral salt medium (MSM) dimana medium tersebut merupakan medium mineral minim sumber karbon. Namun dalam aplikasinya MSM masih memiliki harga yang relatif mahal sehingga diperlukan aplikasi yang lebih ekonomis untuk degradasi plastik dengan memanfaatkan air tawar. Bacillus sp. dapat ditemukan pada sedimen air tawar yang memanfaatkan nutrien sedimen dan perairan baik berupa organik maupun anorganik untuk pertumbuhan selnya [9]. Nutrien di perairan terdapat dalam bentuk makro maupun mikro [10]. Berdasarkan hal tersebut perlu dikaji tentang pengaruh air kolam steril dengan penambahan $1 \mathrm{~g} / \mathrm{L}$ MSG terhadap pertumbuhan dan degradasi plastik kresek oleh bakteri isolat Bacillus PL01 dalam skala laboratorium. Dengan adanya penambahan $1 \mathrm{~g} / \mathrm{L}$ MSG dalam medium air kolam diharapkan pertumbuhan bakteri dan degradasi plastik lebih optimal.

\section{METODOLOGI}

\section{A. Waktu dan Tempat Penelitian}

Penelitian dilakukan di laboratorium Mikrobiologi dan Bioteknologi Departemen Biologi FMIPA ITS Surabaya pada bulan Februari - Juni 2017.

\section{B. Peremajaan Isolat dan Pembuatan Starter}

Isolat Bacillus PL01 disubkulturkan pada medium Nutrient Agar (NA) dengan metode streak continuous. Isolat diinkubasi dalam inkubator dengan suhu $37^{\circ} \mathrm{C}$ selama $24 \mathrm{jam}$. Pembuatan starter dilakukan secara bertingkat yaitu dengan pengambilan inokulum isolat subkultur bakteri sebanyak 1 ose dan dimasukkan ke dalam $10 \mathrm{ml}$ medium Nutrient Broth (NB) dan diinkubasi selama 24 jam. Biakan bakteri dari media NB tersebut diambil $1 \mathrm{ml}$ kemudian dimasukkan ke dalam $9 \mathrm{ml}$ NB baru dan diinkubasi selama 24 jam. Berikutnya biakkan bakteri dmasukkan ke dalam $90 \mathrm{ml} \mathrm{NB}$ baru dan diinkubasi 
selama 24 jam. Selanjutnya biakan bakteri dimasukkan ke dalam $900 \mathrm{ml} \mathrm{NB}$ baru dan diinkubasi selama 24 jam. Biakan bakteri pada NB tersebut merupakan starter dengan kepadatan sel $10^{5}-10^{8} \mathrm{sel} / \mathrm{ml}$ yang dihitung menggunakan Haemacytometer. Starter ini dinamakan starter mikroorganisme.

Selanjutnya dilakukan pembuatatan air kolam steril. Air kolam yang digunakan adalah air kolam 8 ITS. Air kolam 8 ITS diambil $6000 \mathrm{ml}$ dan disaring dengan saringan. Kemudian air kolam disterilisasi dengan menggunakan autoklaf selama 15 menit dengan suhu $121^{\circ} \mathrm{C}$ dan tekanan 1,5 atm. Setiap inkubator berisi $5130 \mathrm{ml}$ air kolam steril dengan atau tanpa penambahan $1 \mathrm{~g} / \mathrm{L}$ MSG dan $570 \mathrm{ml}$ starter mikroorganisme.

\section{Preparasi Kantong Plastik}

Plastik uji yang digunakan berupa plastik pembungkus makanan transparan. Plastik tersebut dipotong dengan ukuran $6 \times 10 \mathrm{~cm} 2$ sebanyak 3 kali ulangan. Penelitian ini merupakan penelitian destruktif selama 12 minggu dengan interval waktu 3 minggu untuk pengambilan data

Plastik disterilisasi dengan menggunakan alkohol $70 \%$ selama kurang lebih 30 menit dan dikeringkan anginkan di UV pada Laminar Air Flow (Bio 60-M®) selama 15 menit dan selanjutnya plastik dimasukkan ke dalam oven pada suhu $80^{\circ} \mathrm{C}$ selama 24 jam. Setelah itu plastik dimasukkan ke dalam desikator selama 24 jam. Plastik dilapisi kawat kassa nyamuk aluminium dengan ukuran $7 \times 11 \mathrm{~cm}$ sebagai pemberat

\section{Biodegradasi Plastik}

Biodegradasi plastik dilakukan dengan menggunakan media air kolam steril. Proses biodegradasi plastik dilakukan pada inkubator kaca berukuran $29 \times 24 \times 12 \mathrm{~cm} 3$. Plastik disusun 2 deret secara horizontal di dalam inkubator dengan masingmasing deret berisi 18 susunan plastik. Susunan plastik tersebut dihubungkan dengan kawat aluminium dengan diameter $1 \mathrm{~mm}$ dan setiap plastik diberi jarak $1 \mathrm{~cm}$. Kemudian starter aplikasi dimasukkan ke dalam inkubator.

Perlakuan biodegradasi ini dilakukan dalam kondisi gelap dengan asumsi bahwa cahaya selama proses degradasi sangat minim. Terdapat 2 kontrol yang digunakan yaitu adalah kontrol air kolam steril dengan/tanpa penambahan MSG $1 \mathrm{~g} / \mathrm{l}$ Proses biodegradasi dilakukan selama 12 minggu dan interval pengamatan 3 minggu sekali dengan 2 parameter yaitu pembentukan biofilm dan proses degradasi plastik. Pembentukan biofilm diukur dengan pengamatan visual biofilm dan pengukuran densitas bakteri uji. Proses degradasi plastik dapat diamati dengan uji velositas plastik.

\section{E. Pengukuran Kerapatan Sel dan Pewarnaan Sel pada Biofilm}

Pembentukan biofilm dapat diamati dengan pengukuran kerapatan sel biofilm bakteri yang terbentuk pada permukaan plastik. Sebelumnya kawat kassa aluminium dilepas dari plastik. Kerapatan sel pada biofilm dilakukan dengan pemisahan biofilm bakteri pada permukaan plastik dengan cara plastik dimasukkan ke dalam botol falcon $50 \mathrm{ml}$ yang berisi $20 \mathrm{ml}$ aquades steril dan divortex selama 10 detik sebanyak 3 kali. Kemudian $2 \mathrm{ml}$ supernatant diambil dan dimasukkan ke dalam kuvet selanjutnya diukur absorbansinya menggunakan spektrofotometer pada panjang gelombang 600 $\mathrm{nm}$. Pengukuran absorbansi ini dilakukan sebanyak 3 kali pengulangan. Perhitungan kerapatan sel dilakukan setiap 3 minggu selama 12 minggu. Sebagai pembanding kerapatan sel pada kolom air dapat diukur dengan cara yang sama. Kerapatan sel diukur dengan menentukan 3 titik secara acak pada kolom air.

Pewarnaan biofilm dilakukan dengan cara sisa supernatan yang telah diperoleh dari pengukuran kerapatan sel pada biofilm diambil dengan menggunakan pipet. Kemudian satu tetes supernatan diletakkan pada kaca objek. Preparat difiksasi di atas Bunsen dan diberi pewarna methylene blue dan didiamkan selama 1 menit. Preparat dibilas dengan aquades dan dibiarkan hingga kering. Preparat yang sudah kering selanjutnya ditutup dengan kaca penutup. Setelah itu preparat diamati dengan menggunakan mikroskop dengan perbesaran 1000x

\section{F. Velositas Plastik}

Plastik yang telah dihitung berat keringnya dapat dilanjutkan untuk uji velositas plastik. Uji velositas plastik dapat dihitung berdasarkan waktu pergerakan yang dibutuhkan plastik dari dasar inkubator hingga ke permukaan inkubator. Plastik dimasukkan ke dalam inkubator yang telah diisi aquades sampai ketinggian $10 \mathrm{~cm}$ dengan spatula steril. Waktu pergerakan plastik dari dasar inkubator sampai ke permukaan inkubator dicatat sebagai waktu velositas [11].

\section{HASIL DAN PEMBAHASAN}

\section{A. Pengaruh Monosodium Glutamat (MSG) Terhadap Pertumbuhan Bacillus PLO1}

Penelitian ini menggunakan air kolam steril sebagai mediumnya. Proses Degradasi dilakukan selama 12 minggu masa inkubasi dengan interval waktu 3 minggu untuk pengambilan data. Gambar 1 merupakan grafik kepadatan sel biofilm Bacillus PL01 dengan/tanpa penambahan $1 \mathrm{~g} / \mathrm{L}$ MSG selama 12 minggu masa inkubasi. Pertumbuhan biomassa biofilm menunjukkan Bacillus PL01 dapat hidup dan menempel pada permukaan plastik. Hal ini menunjukkan bahwa kedua bakteri tersebut dapat beradaptasi dan memanfaatkan air kolam sebagai nutrisi alternatif untuk pertumbuhannya. Biofilm adalah kumpulan bakteri interaktif yang dibungkus dalam matriks eksopolisakarida dan melekat pada permukaan yang keras atau melekat satu sama lain. Satu spesies bakteri atau lebih dapat terlibat dan berkumpul bersama untuk membentuk biofilm [12]. 


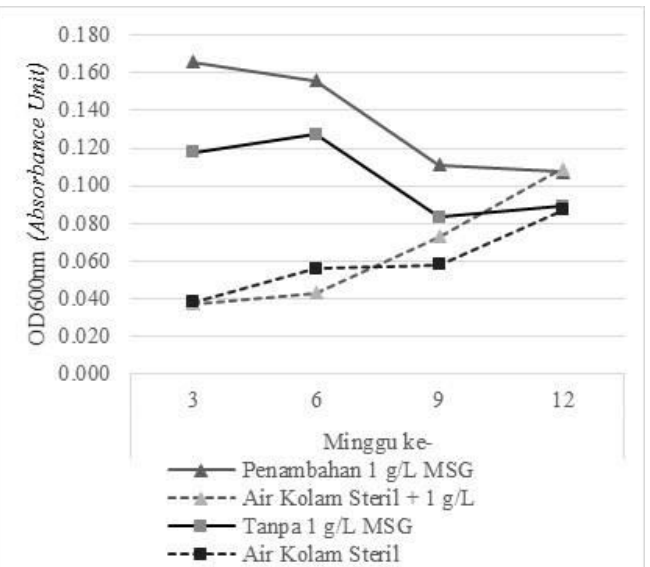

Gambar 1. Hasil Kepadatan Sel Bacillus PL01 dan pada Permukaan Plastik Transparan.

Pertumbuhan biofilm berdasarkan nilai serapan OD600nm, terlihat pada Bacillus PL01 dengan penambahan $1 \mathrm{~g} / \mathrm{L}$ MSG selama 12 minggu masa inkubasi pertumbuhannya cenderung menurun. Pada minggu ke-3 pertumbuhannya pada plastik transparan adalah 0,166 AU kemudian menurun menjadi 0,107 AU pada minggu ke-12. Bacillus PL01 tanpa penambahan 1 $\mathrm{g} / \mathrm{L}$ MSG terlihat pertumbuhannya juga menurun, namun mengalami kenaikan kembali pada minggu ke-12 masa inkubasi yaitu 0,089 AU. Pertumbuhan biomassa biofilm dengan penambahan $1 \mathrm{~g} / \mathrm{L}$ MSG masih lebih tinggi jika dibandingkan dengan tanpa penambahan $1 \mathrm{~g} / \mathrm{L}$ MSG.

Sedangkan pada kontrol air kolam steril dengan/tanpa penambahan MSG juga terdeteksi adanya pertumbuhan biomassa biofilm; dengan penambahan 1 g/L MSG pertumbuhannya lebih tinggi dibandingkan tanpa $1 \mathrm{~g} / \mathrm{L}$ MSG. Pertumbuhan biofilm kontrol pada permukaan plastik transparan dengan penambahan $1 \mathrm{~g} / \mathrm{L}$ MSG pada minggu ke12 adalah 0,109 AU. Pertumbuhan ini menunjukkan bahwa masih terdapat dan bertahan bakteri indigenous air kolam pada suhu tinggi walaupun air tersebut sudah disterilisasi dengan autoclave pada suhu $121^{\circ} \mathrm{C}$ pada $1,5 \mathrm{~atm}$. Bakteri bertahan tersebut diduga dapat tumbuh dan berkembang biak dalam inkubator selama 12 minggu masa inkubasi. Bakteri pembentuk spora merupakan species yang dapat bertahan hidup setelah dipanaskan dengan uap $100^{\circ} \mathrm{C}$ bahkan lebih [13]. Spora tahan terhadap temperatur yang mematikan sel vegetatif, seperti contoh spora Clostridium botulinum tahan terhadap temperatur mendidih selama beberapa jam [14]. Meskipun demikian pertumbuhan biofilm pada kontrol tidak sebesar pertumbuhan Bacillus PL01

Dari hasil kepadatan sel biofilm dapat dikatakan bahwa Bacillus PL01 dapat memanfaatkan MSG untuk pertumbuhannya, meskipun pertumbuhan kedua bakteri tersebut menunjukkan respon yang berbeda terhadap MSG sebagai nutrisi tambahan selain medium air kolam. Penurunan pertumbuhan Bacillus PL01 dengan penambahan 1 g/L MSG

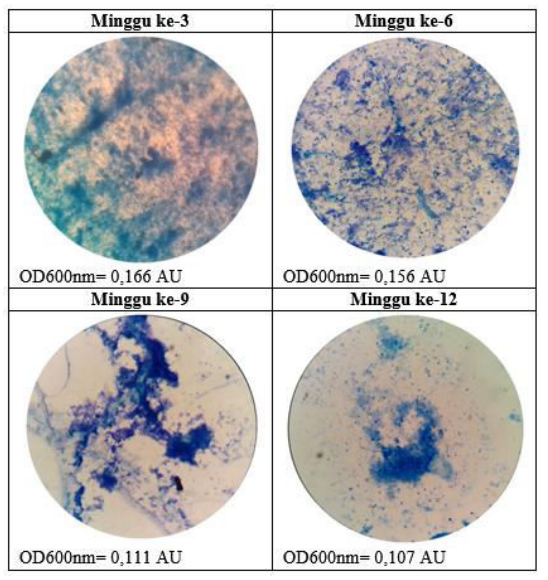

Gambar 2. Visualisasi Biofilm Plastik Transparan pada Bacillus PL01 dengan penambahan $1 \mathrm{~g} / \mathrm{L}$ MSG dengan perbesaran 1000x.

seakan mengindikasi bahwa Bacillus PL01 dapat memanfaatkan air kolam dan MSG sebagai sumber nutrisi secara bersamaan sehingga ketika nutrisi tersebut habis maka pertumbuhannya juga menurun. Air tawar (freshwater) menyediakan nutrisi baik makronutrien maupun mikronutrien yang dapat dimanfaatkan mikroorganisme untuk pertumbuhannya [15]. Sedangkan Glutamat dimanfaatkan sebagai substrat untuk sintesis protein sehingga dapat membentuk material sel. Selain itu glutamat merupakan prekursor glutamin yang bermanfaat dalam metabolisme karbon dan nitrogen [16].

Dari Gambar 2 dapat dilihat visualisasi kerapatan sel biofilm Bacillus PL01 dengan penambahan $1 \mathrm{~g} / \mathrm{L}$ MSG pada medium air kolam pada plastik hitam. Semakin mencolok warna biru yang dihasilkan maka diasumsikan biofilm yang terdapat pada permukaan plastik semakin tebal. Warna biru tersebut merupakan indikator sel biofilm yang menempel pada permukaan plastik. Warna biru dihasilkan dari ikatan antara dinding sel dengan pewarna methylene blue yang menunjukkan banyaknya sel bakteri. Kenampakan biofilm di bawah mikroskop dengan menggunakan pewarnaan methylene blue memiliki korelasi sebanding dengan nilai OD600nm [17]. Nilai serapan OD600nm yang rendah memiliki struktur yang lebih renggang dilihat dari warna methylene blue yang pudar dan tidak mencolok. Sedangkan nilai serapan OD600nm biofilm yang lebih tinggi terlihat memiliki struktur yang lebih rapat dan warna mencolok.

Penelitian ini juga dilakukan perbandingan antara pertumbuhan Bacillus PL01 pada permukaan plastik dan kolom perairan. Meskipun pertumbuhan sel bakteri pada kolom perairan dan permukaan plastik menunjukkan rentang pertumbuhan yang tidak terlalu berbeda, namun Gambar 3 dapat menunjukkan bahwa pertumbuhan biomassa biofilm pada permukaan plastik lebih stabil. Ketika nutrisi air kolam habis maka bakteri akan mencari nutrisi alternatif dengan lebih memilih menempel pada permukaan plastik. 


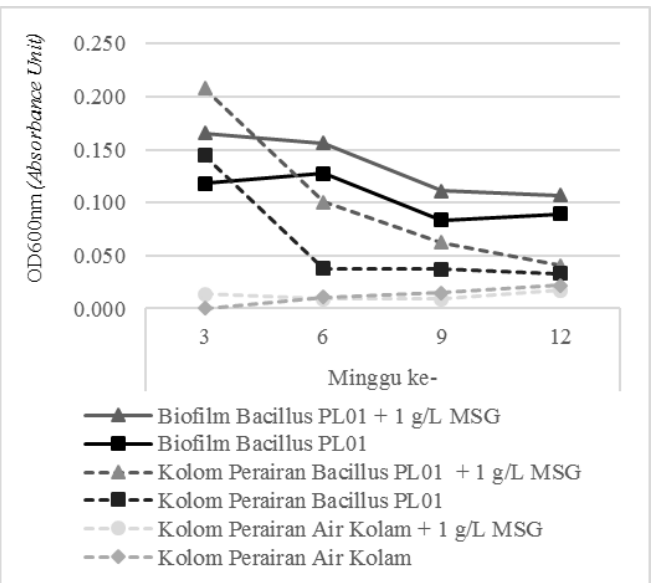

Gambar 3. Grafik Perbandingan Kerapatan Sel Biofilm pada Permukaan plastik dan Kolom Perairan Inkubator.

Pada Gambar 3 menunjukan bahwa secara umum pertumbuhan sel Bacillus PL01 pada kolom perairan mengalami penurunan selama 12 minggu masa inkubasi. Pertumbuhan sel kolom perairan Bacillus PL01 dengan $1 \mathrm{~g} / \mathrm{L}$ MSG pada minggu ke-3 adalah 0,28 AU dan turun menjadi 0,041 pada minggu ke-12, Bacillus PL01 tanpa $1 \mathrm{~g} / \mathrm{L}$ MSG dari 0,144 AU menjadi 0,03 AU. Secara umum bakteri lebih memilih untuk tumbuh pada suatu permukaan yang tersedia daripada di sekitar perairan [18]. Mikroorganisme yang menempel pada permukaan suatu substrat biasanya akan membentuk biofilm [19]. Pembentukan biofilm pada suatu permukaan merupakan mekanisme bakteri untuk mendapatkan nutrien. Matriks polimer ekstraseluler pada biofilm terdiri atas EPS yang mampu menghimpun nutrien melalui absorpsi [20].

\section{B. Pengaruh Bacillus PLO1 pada Waktu Apung (Velositas) Plastik}

Gambar 3 menunjukkan bahwa pertumbuhan biofilm pada plastik lebih tinggi jika dibandingkan pada kolom perairan. Hal ini menunjukkan ketika nutrisi air kolam habis maka bakteri akan mencari nutrisi alternatif lain dengan menempel pada substrat. Ketika menempel pada plastik maka bakteri mampu memanfaatkan plastik sebagai sumber karbon dan energinya dengan memecah polimer plastik secara enzimatik. Penempelan biofilm dan pemecahan polimer tersebut merupakan salah satu proses biodegradasi. Sehingga untuk mengetahui terjadinya degradasi pada plastik tersebut dilakukan parameter waktu apung plastik (velositas). Pengukuran velositas dilakukan untuk mengetahui sifat hidrofobisitas plastik selama 12 minggu masa inkubasi. Plastik jenis polietilen bersifat inert karena memiliki rantai molekul hidrofobik dan berat molekul yang besar [21]. Polietilen yang tidak didegradasi memiliki ikatan non polar antar monomer $\mathrm{CH}_{2}$ oleh sebab itu sifat permukaannya sangat hidrofobik [22][23]. Aktivitas enzimatik yang dilakukan oleh mikroorganisme dalam mendegradasi menyebabkan menurunnya berat molekul dan hidrofobisitas polimer [24]. Pengukuran velositas tersebut dapat dilakukan dengan membandingkan lama pengapungan plastik antara sebelum dan sesudah perlakuan di dalam air. Untuk mengetahui sifat

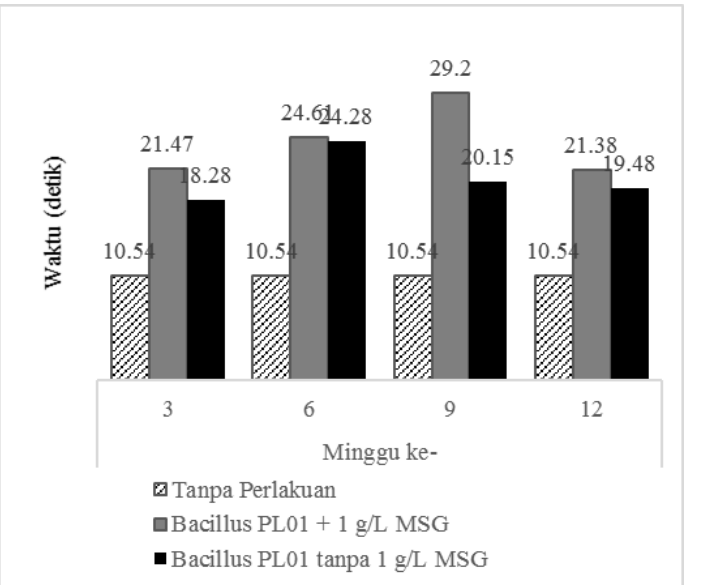

Gambar 4. Velositas Plastik yang Didegradasi oleh Bacillus PL01 dan Pseudomonas PL01.

awal plastik, pada pengukuran velositas terdapat kontrol awal yaitu plastik yang tidak diinkubasi.

Gambar 4 menunjukkan plastik kontrol tanpa perlakuan memiliki waktu apung (velositas) 10,54 detik. Velositas pada plastik yang telah didegradasi selama 12 minggu masa inkubasi terlihat lebih lama dibandingkan dengan kontrol. Pada Bacillus PL01 dengan $1 \mathrm{~g} / \mathrm{L}$ MSG velositas pada plastik pada minggu ke-12 masa inkubasi mencapai 21,38 detik. Pada Bacillus PL01 tanpa $1 \mathrm{~g} / \mathrm{L}$ mencapai 19,48 detik. Hal ini membuktikan bahwa selama masa inkubasi Bacillus PL01 dapat menurunkan sifat hidrofobisitas plastik. Pada proses biodegradasi terjadi penambahan gugus hidroksil untuk menurunkan tegangan permukaan plastik sehingga hidrofobisitas plastik akan menurun. Penurunan hidrofobisitas plastik tersebut juga akan mempengaruhi persebaran plastik di lingkungan perairan [11].

Hasil pengukuran velositas ini berkolerasi pada hasil kepadatan sel biofilm pada permukaan plastik (Gambar 1). Semakin tingginya pertumbuhan biofilm pada permukaan plastik maka semakin turun hidrofobisitas plastik tersebut. Hidrofobisitas pada plastik merupakan sifat penting dari permukaan plastik dalam proses biodegradasi. Hal in disebabkan karena adanya hubungan antara hidrofobisitas permukaan plastik dengan kemampuan mikroorganisme dalam berkolonisasi pada substrat polimer. Semakin hidrofilik suatu permukaan maka akan lebih mudah suatu mikroorganisme untuk menempel dan berkolonisasi [24]. Hasil biodegradasi pada polietilen akan semakin efisien jika mikroorganisme pendegradasi tersebut dapat membentuk biofilm pada permukaan polietilen [25]. Adanya aktivitas enzimatik pada bakteri akan memecah substrat polimer menjadi oligomer yang memiliki berat molekul lebih rendah. Beberapa oligomer tersebut selanjutnya akan berikatan dengan air dan menjadi produk intermediet organik seperti alkohol dan keton. Dan masuknya oksigen pada permukaan plastik akan membentuk gugus fungsi baru yaitu karbonil $(\mathrm{C}=\mathrm{O})$ dan hidroksil $(\mathrm{O}-\mathrm{H})$ dimana kedua gugus tersebut lebih mudah didegradasi [22]. Ketika terjadi kontak dengan air, maka gugus karbonil yang terdapat pada suatu polimer akan membentuk ikatan hidrogen dengan molekul air [26]. 


\section{KESIMPULAN}

Kesimpulan dari penelitian ini adalah Pertumbuhan biofilm Bacillus PL01 dengan $1 \mathrm{~g} / \mathrm{L}$ MSG pada permukaan plastik menurun menjadi 0,107 AU. Plastik yang telah didegradasi membutuhkan waktu apung lebih lama dibandingkan kontrol tanpa perlakuan, yaitu pada Bacillus PL01 dengan $1 \mathrm{~g} / \mathrm{L} \mathrm{MSG}$ mencapai 21,38 detik dari kondisi semula selama 10.54 detik.

\section{DAFTAR PUSTAKA}

[1] H. Y. Darni and S. N. Arsiah, "Peningkatan Hidrofobisitas dan Sfat Fisik Plastik Biodegradable Pati Tapioka dengan Penambahan Selulosa Residu Rumput Laut (Euchema spinossum').," Universitas Lampung, 2010.

[2] E. Fitriani, "Industri Plastik Raih Omzet Rp. 30 Triliun," 2016. [Online]. Available: http://www.beritasatu.com/ekonomi/328416-industri-plastikraup-omzet-rp-130-triliun.html/.

[3] A. Ibiene, H. Stanley, and O. Immanuel, "Biodegradation of Polyethylene by Bacillus sp. Indigenous to The Niger Delta Mangrove Swamp," Niger. J. Biotechnol., vol. 26, pp. 68-79, 2013.

[4] N. Lucas, C. Bienaime, C. Belloy, M. Queneudec, F. Silvestre, and J. E. Nava-Saucedo, "Polymer Biodegradation: Mechanisms and Estimation Techniques-A review," J. Chemosph., vol. 73, no. 4, pp. 429-442, 2008.

[5] K. Leja and L. G., "Polymer Biodegradation and Biodegradable Polymers-a Review," Polish J. Environ. Stud., vol. 19, no. 2, pp. 225226, 2009.

[6] H. Nuryani and S. Jinap, "Soy Sauce and its Umami Taste: A Link from The Past To Current Situation,” J. Food Sci., vol. 5, no. 3, pp. 71-76, 2010.

[7] I. Koike and Hattori, "Growth Yield of a Denitrifying Bacterium, Pseudomonas denitrificans under Aerobic an denitrifying conditions," $J$. Gen. Microbiol., vol. 88, pp. 1-10, 1975.

[8] L. Mufroh and M. Shovitri, "Degradasi Plastik Oleh Bakteri Bacillus P101 dan Pseudomonas P101 dengan Penambahan 1 G/L Monosodium Glutamat (Msg)," Institut Teknologi Sepuluh Nopember, 2016.

[9] D. Jumiarni, "Isolasi dan Identifikasi Bakteri Sedimen Waduk," 2007.

[10] H. . Bold and M. . Wayne, Introduction to Algae. New Jersey: Prentice Hal, Inc, 1985

[11]J. Reisse, B. Slat., K. Noble., D. Pleises., and M. Epp, "The Vertical Distribution of Buoyant Plastics at Sea: an observational study in the
North Atlantic Gyre,” J. Biogeosciences, vol. 12, pp. 1249-1256, 2015.

[12]F. Brooks, G et al., Medical Microbiology. Mc Graw Hill, 2010.

[13] R. Melliawati, "Eschericia coli dalam kehidupan manusia," J. Bio Trends, vol. 4 , no. $1,2009$.

[14]L. Waluyo, Mikrobiologi Umum. Malang: UPT Penerbit UMM, 2007.

[15]T. Downs, M. Schallenberg, and C. W. Burns, "Responses of Lake Phytoplankton to Micronutrient Enrichment: a Study In Two New Zealand Lakes and an Analysis of Published data," Aquat. Sci., vol. 70, pp. 347-360, 2010.

[16] A. Meister, Biochemistry of Glutamate : Glutamine and Glutathione. New York: Raven Press, 1979.

[17]P. Thomen, J. Robert, A. Monmeyran, and H. N. Bitbol A-F, Douarche C, "Bacterial Biofilm Under Flow: First a Physical Struggle to Stay, then a Matter of Breathing," PLoS One, vol. 12, no. 4, 2017.

[18]X. Tang, "Controlling Biofilm Development on Ultrafiltration and Reverse Osmosis Membranes Used in Dairy Plants," Massey University, 2011.

[19]G. A. O'toole and R. Kolter, "Initiation of Biofilm formation in Pseudomonas fluorescens WCS365 Proceeds Via Multiple, Convergent Signalling Pathways: A Genetic Analysis," Mol. Microbiol., vol. 28, no. 3, pp. 449-461, 19998.

[20]M. A. Hamon and B. A. Lazazzera, "The Sporulation Transcription Factor Spo0A is required for Biofilm Development in Bacillus subtilis," Mol. Microbiol., vol. 42, no. 5, pp. 1199-1209, 2011.

[21]B. Suresh, S. Maruthamuthu, and M. Kannan, "Mechanical and Surface Properties of Low-Density Polyethylene Film Modified by PhotoOxidation," Polym. J., vol. 43, pp. 398-406, 2011.

[22] J. Arutchelvi, M. Sudhakar, A. Arkatkar, M. Doble, S. BAdhuri, and P. V. Uppara, "Biodegradation of Polyethylene and Polypropylene," Indian J. Biotechnol., vol. 7, no. 9-22, 2008.

[23]M. B. Kazimi, I. Ahmed, and C. K. . Faizal, "A Short Review of Hydrophilic Surface Modification Methods for Low Density Polyethylene," Int. Conf. Chem. Innov., 2011.

[24]K. Sen and S. Raut, "Microbial degradation of low density polyethylene (LDPE): A review," J. Environ. Chem. Eng., vol. 3, pp. 462-473, 2015.

[25]D. Hadad, H. Geresh, and A. Sivan, "Biodegradation of Polyethylene by the Thermophilic Bacterium Brevibacillus borstelensis," J. Appl. Microbiol., vol. 98, pp. 1093-1100, 2005.

[26]W. J. Lee, J. G. Chang, and S. P. Ju, "Hydrogen-Bond Structure at the Interfaces between Water/Poly(methyl methacrylate), Water/Poly (methacrylic acid), and Water/Poly(2-aminoethylmethacrylamnide)," Langmuir, vol. 26, no. 15, pp. 12640-12647, 2010. 